\title{
El despido del trabajador por motivo de sus ausencias al trabajo tras las últimas reformas laborales
}

\author{
Josep Moreno Gené, Ana María Romero Burillo* \\ Universitat de Lleida \\ jmoreno@dpub.udl.cat; aromero@dpub.udl.cat
}

Resumen: El estudio que se lleva a cabo en este trabajo pretende, a partir del análisis de la extinción del contrato por ausencias del trabajador, ya sea en su vertiente de extinción por causas objetivas prevista en el artículo 52 d) ET o en su vertiente de despido disciplinario previsto en el artículo 54.2.a) ET, mostrar los dos elementos definidores de la incidencia de las reformas laborales del 2012 en la extinción del contrato de trabajo, a saber, que el despido del trabajador sea mucho más sencillo y más económico. A tal efecto, se efectúa, en primer lugar, el análisis de la reformulación de la causa de extinción del contrato por ausencias del trabajador prevista en el artículo 52 d) ET que ha venido a desbloquear esta vía de extinción del contrato en beneficio del empleador. En segundo lugar, se lleva a cabo un estudio de los efectos que a partir de ahora se desprenden de la declaración de improcedencia del despido del trabajador por sus ausencias al trabajo, ya se trate de las previstas en el artículo 54.2. a) ET o de las contempladas en el artículo 52 d) ET, no en vano en ambos supuestos se ba visto sustancialmente reducida la cuantía de la indemnización prevista y prácticamente eliminados los salarios de tramitación.

Palabras clave: absentismo laboral, extinción del contrato, reforma laboral, costes del despido.

\footnotetext{
* Los autores son miembros del grupo de investigación consolidado de la Generalitat de Catalunya Análisis Social y Organizativo (2009 SGR 310).
} 


\begin{abstract}
By analyzing contract termination because of absence from work for both objective reasons (article 52 d) ET) and disciplinary dismissal (article 52.4 a) ET), this article aims to discuss the two defining aspects of the effect of the labour reforms of 2012 on the termination of work contracts: namely, that the dismissal of a worker is much simpler and much more economical. To this end, we first analyse the reformulation of the cause of termination because of absence from work covered by article $52 d$ ) ET, which has made it easier for employers to terminate contracts by this means. Then we study the effects of the declaration of unfair dismissal because of absence from work covered in both article 54.2 a) ET and article 52 d) ET. In both cases, the amount of compensation has been considerably reduced and procedural salaries have virtually been done away with.
\end{abstract}

Keywords: absenteeism, contract termination, labour reform, dismissal costs. 


\section{Introducción ${ }^{1}$}

Una de las materias estrella de las reformas laborales del 2012 llevadas a cabo inicialmente por el Real Decreto 3/2012, de 10 de febrero, de medidas urgentes para la reforma del mercado laboral (en adelante, Real Decreto 3/2012), y, posteriormente, por la Ley 3/2012, de 6 de julio, de medidas urgentes para la reforma del mercado laboral (en adelante, Ley $3 / 2012$ ), ha sido, sin lugar a dudas, la reforma de la extinción del contrato de trabajo. En esta dirección, de un modo muy gráfico se ha indicado que «una parte de las reformas se mueven, en efecto, en el terreno del desbloqueo de formas extintivas en interés de la empresa. Se modifican, bien que de forma limitada, algunas causas extintivas del despido objetivo y, sobre todo, la ordenación de los despidos colectivos. Y, en este último terreno, los temas afectados vuelven a ser los de siempre: la causalidad y el procedimiento. La otra parte de las nuevas reglas se refieren a los costes del despido injusto; y de nuevo en terrenos conocidos: cuantía de la indemnización por despido improcedente y tratamiento de los salarios de tramitación $»^{2}$.

Ambas medidas han sido merecedoras de importantes críticas desde diferentes sectores que consideran que las medidas adoptadas en materia de extinción del contrato de trabajo van dirigidas a facilitar que el despido sea mucho más sencillo, eliminando todas las trabas existentes hasta el momento, y más eficiente, es decir, más ventajoso o beneficioso. En otros términos, con la reforma laboral «no ya solo se va a liberar buena parte, si no todos, los obstáculos que había para despedir, sino a procurar que sea también al menor coste posible» ${ }^{3}$.

El estudio que se lleva a cabo en este trabajo pretende, a partir del análisis de la extinción del contrato por ausencias del trabajador, ya sea en su vertiente de extinción por causas objetivas prevista en el artículo 52 d) ET o en su vertiente de despido disciplinario previsto en el artículo 54.2.a) ET, mostrar estas dos manifestaciones de la incidencia de las reformas laborales del 2012 en la extinción del contrato de trabajo, a saber, que el despido del trabajador sea mucho más sencillo y económico. A tal efecto, se efectúa, en primer lugar, el análisis de la reformulación de la causa de extinción del contrato por ausencias del trabajador prevista en el artículo 52 d) ET, que al suprimir la tradicional exigencia de un nivel de absentismo colectivo junto con el nivel de absentismo individual del tra-

1 Este trabajo se enmarca en el proyecto de investigación DER 2010-21686-C02-02, concedido por el Ministerio de Ciencia e Innovación, que lleva por título «La gestión del absentismo laboral: medición, impacto económico, causas sociales y psicológicas y régimen jurídico laboral».

2 Vid. Goerlich Peset, J. M. (2012). «La extinción del contrato de trabajo en el Real Decreto-Ley 3/2012: la culminación de una larga evolución», en I García-Perrote Escartín y J. R. Mercader Uguina (2012). Reforma laboral 2012. Valladolid: Lex Nova, págs. 293 y 294.

3 Molina Navarrete, C. (2012). «De las «reformas laborales» a un nuevo, e irreconocible, «estatuto del trabajo subordinado»». Revista de Trabajo y Seguridad Social, núm. 348, pág. 82. 
bajador, ha venido a desbloquear esta vía de extinción del contrato en beneficio del empleador, mutando el verdadero fundamento de esta causa de extinción del contrato. En segundo lugar, se lleva a cabo un estudio de los efectos que a partir de ahora se desprenden de la declaración de improcedencia del despido del trabajador por sus ausencias al trabajo, ya se trate de las previstas en el artículo 54.2. a) ET o de las contempladas en el artículo 52 d) ET. En ambos supuestos se ha visto sustancialmente reducida la cuantía de la indemnización prevista, así como prácticamente eliminados los salarios de tramitación.

\section{La extinción del contrato por absentismo laboral tras la reforma laboral del 2012}

\subsection{La reformulación de la causa de extinción del contrato por absentismo laboral}

La redacción actual del apartado primero del artículo 52 d) ET prevé la posibilidad de que el contrato de trabajo pueda extinguirse «por faltas de asistencia al trabajo, aun justificadas pero intermitentes, que alcancen el 20\% de las jornadas hábiles en dos meses consecutivos siempre que el total de faltas de asistencia en los doce meses anteriores alcance el cinco por ciento de las jornadas hábiles, o el $25 \%$ en cuatro meses discontinuos dentro de un período de doce meses». El apartado segundo del citado precepto matiza el alcance de dicha causa extintiva del contrato de trabajo al prever que «no se computarán como faltas de asistencia [...] las ausencias debidas a huelga legal por el tiempo de duración de la misma, el ejercicio de actividades de representación legal de los trabajadores, accidente de trabajo, maternidad, riesgo durante el embarazo y lactancia, enfermedades causadas por embarazo, parto o lactancia, paternidad, licencias y vacaciones, enfermedad o accidente no laboral, cuando la baja haya sido acordada por los servicios sanitarios oficiales y tenga una duración de más de veinte días consecutivos, ni las motivadas por la situación física o psicológica derivada de violencia de género, acreditada por los servicios sociales de atención o servicios de Salud, según proceda. Tampoco se computarán las ausencias que obedezcan a un tratamiento médico de cáncer o enfermedad grave». La extensión de supuestos que no computan como faltas de asistencia limita mucho la identificación de las ausencias computables, que prácticamente quedan reducidas a las enfermedades o accidentes no laborales que tengan una duración inferior a veinte días o cuando, siendo superiores a este plazo, no hayan sido acordadas por los servicios sanitarios oficiales. 
A partir de este enunciado pueden identificarse diferentes requisitos para que opere esta causa de extinción contractual: 1 ) debe tratarse de faltas de asistencia al trabajo y no de meras faltas de puntualidad;2) debe tratarse de faltas de asistencia al trabajo que sean computables; 3) las faltas de asistencia computables pueden ser justificadas e injustificadas; 4) debe tratarse de faltas intermitentes, no siendo suficiente un único proceso de ausencia; 5) las faltas de asistencia del trabajador deben alcanzar una determinada entidad, es decir, deben superar un determinado porcentaje en un período de tiempo concreto, en particular, deben alcanzar el $20 \%$ de las jornadas hábiles en dos meses consecutivos, siempre que el total de faltas de asistencia en los doce meses anteriores alcance el $5 \%$ de las jornadas hábiles, o el $25 \%$ en cuatro meses discontinuos dentro de un período de doce meses.

El artículo 52 d) ET, por lo tanto, no habilita al empresario a extinguir el contrato de los trabajadores ante cualquier ausencia de estos, sino que únicamente se apareja esta posibilidad a aquellos supuestos de absentismo que el legislador considera suficientemente relevantes ${ }^{4}$. Tradicionalmente, esta relevancia o suficiente entidad del absentismo se había vinculado al cumplimiento simultáneo de una doble exigencia cuantitativa:

a) La primera exigencia, que si bien con alguna modificación se mantiene tras la Ley $3 / 2012$, consiste en que el número de faltas de asistencia del trabajador que va a ser despedido supere un determinado porcentaje. Esta exigencia, a su vez, puede verse satisfecha por dos vías distintas: 1) cuando las faltas de asistencia alcancen el $20 \%$ de las jornadas hábiles en dos meses consecutivos, siempre que el total de faltas de asistencia en los doce meses anteriores alcance el 5\% de las jornadas hábiles; y 2) cuando las faltas de asistencia alcancen el 25\% de las jornadas hábiles en cuatro meses discontinuos dentro de un período de doce meses.

b) La segunda exigencia, suprimida tras el Real Decreto-Ley 3/2012 y la Ley 3/2012, consistía en que el resto de la plantilla del centro de trabajo también superara una determinada barrera de absentismo en los mismos períodos de tiempo tenidos en cuenta para determinar las faltas de asistencia del trabajador, la cual, si bien se había fijado inicialmente en un $5 \%$, tras la reforma introducida por la Ley 35/2010 quedó reducida al 2,5\%.

En consecuencia, la relevancia o suficiente entidad del absentismo no se vinculaba únicamente a las ausencias al trabajo del trabajador en cuestión, es decir,

4 En esta dirección, Altés Tárrega, J. A., Blasco Pellicer, A. y Nores Torres, L. E. (2010). El despido objetivo. Valencia: Tirant lo Blanch, pág. 47, indican que «el texto estatutario se preocupa por delimitar el absentismo que considera relevante a efectos de entender justificada la extinción del contrato y para ello exige que el mismo presente cierta entidad». En idénticos términos, Alzaga Ruiz, I. (2011). «El absentismo del trabajador como causa de despido objetivo». Revista Española de Derecho del Trabajo, núm. 150, pág. 400, indica que «el absentismo, para ser causa de despido objetivo, ha de presentar una cierta entidad». 
al absentismo individual de este, sino que también se exigía que el resto de la plantilla del centro de trabajo superara una determinada barrera de absentismo colectivo en los mismos períodos de tiempo que se han tenido en cuenta para determinar las faltas de asistencia del trabajador y que tras la reforma introducida por la Ley 35/2010 se había situado en el 2,5\%.

El Real Decreto-Ley 3/2012 en un primer momento y posteriormente la Ley $3 / 2012$, sin embargo, han procedido a eliminar la exigencia de un determinado nivel de absentismo total de la plantilla del centro de trabajo para que pueda operar la causa de extinción del contrato prevista en el artículo 52 d) ET, de modo que, a partir de dichas normas, para que las ausencias al trabajo del trabajador sean relevantes a los efectos de esta causa de extinción del contrato será suficiente con que el número de faltas de asistencia del trabajador que va a ser despedido supere un determinado porcentaje, a saber, que las faltas de asistencia alcancen el $20 \%$ de las jornadas hábiles en dos meses consecutivos, siempre que el total de faltas de asistencia en los doce meses anteriores alcance el 5\% de las jornadas hábiles, o bien que las faltas de asistencia alcancen el 25\% de las jornadas hábiles en cuatro meses discontinuos dentro de un período de doce meses.

Veamos a continuación cómo han quedado definidos los requisitos de absentismo individual y de absentismo colectivo tras las recientes reformas laborales.

\section{A) El nivel de absentismo del trabajador}

La exigencia contenida en el artículo 52 d) ET de que el número de faltas de asistencia al trabajo de un mismo trabajador necesarias para justificar la extinción de su contrato alcancen un determinado porcentaje puede ser satisfecha de dos formas distintas. En primer lugar, que las faltas de asistencia alcancen el 20\% de las jornadas hábiles en dos meses consecutivos, siempre que el total de faltas de asistencia en los doce meses anteriores alcance el $5 \%$ de las jornadas hábiles, y, en segundo lugar, que las faltas de asistencia alcancen el $25 \%$ de las jornadas hábiles en cuatro meses discontinuos dentro de un período de doce meses, correspondiendo al empresario la elección de uno u otro módulo de cálculo de conformidad con las circunstancias concurrentes en cada caso.

La exigencia de que la inasistencia al trabajo deba prolongarse por un espacio de dos meses o de cuatro meses discontinuos encuentra su fundamento en no endurecer en demasía esta forma de extinción del contrato, como sucedería si se refiriera únicamente a un mes concreto. Asimismo, existe una relación directa entre el período de referencia que se tome en cuenta y el porcentaje de ausencias exigido, de modo que a un período de referencia más corto - dos meses- se exige un menor porcentaje de ausencias - el 20\%—, mientras que a un período 
de referencia más extenso y dilatado en el tiempo - cuatro meses en un período de referencia de doce- se exige un porcentaje de ausencias más elevado - el $25 \%$ -

Una vez que se ha optado por cualquiera de los dos módulos de cálculo de las ausencias del trabajador, a saber, el $20 \%$ de las jornadas hábiles en dos meses consecutivos, siempre que el total de faltas de asistencia en los doce meses anteriores alcance el $5 \%$ de las jornadas hábiles, y el $25 \%$ de las jornadas hábiles en cuatro meses discontinuos dentro de un período de doce meses, del tenor literal del precepto se desprende que es suficiente con que las ausencias al trabajo alcancen los citados porcentajes sin que sea necesario que estos se superen.

A pesar de que a priori el porcentaje de faltas de ausencia exigidas para justificar el recurso a esta vía de extinción del contrato de trabajo - el $20 \%$ de las jornadas hábiles en dos meses consecutivos o el $25 \%$ de las jornadas hábiles en cuatro meses discontinuos dentro de un período de doce meses- puede parecer elevado, si se cuantifica de un modo más concreto se observa que puede recurrirse a esta vía de extinción del contrato cuando concurre un número relativamente bajo de ausencias del trabajador. En esta dirección, a título de ejemplo se ha indicado que el porcentaje del $20 \%$ de las jornadas hábiles en dos meses consecutivos puede verse satisfecho con 9 días laborales de ausencia, ya que estas pueden representar el exigido $20 \%$ del total de días laborales en un período de dos meses ordinarios, que pueden ser 42 días. En estos supuestos, es cuanto menos cuestionable que con estas ausencias se pueda frustrar el interés empresarial en la vigencia de la relación laboral ${ }^{6}$. El limitado número de ausencias del trabajador que pueden satisfacer los parámetros exigidos por el artículo 52 d) ET resulta mucho más preocupante tras la reforma laboral introducida por el Real Decreto-Ley $3 / 2012$, puesto que, como ya se ha indicado, ante la eliminación del requisito del absentismo colectivo, estas pueden justificar por si solas la extinción del contrato de trabajo del trabajador ausente.

En este punto cobra todo su significado la novedad introducida por la Ley 3/2012 para el supuesto en que se acuda a la primera posibilidad de extinción del contrato de trabajo por ausencias del trabajador previstas en el artículo $52 \mathrm{~d}$ ) ET, es decir, cuando se acrediten «faltas de asistencia al trabajo, aun justificadas pero intermitentes, que alcancen el $20 \%$ de las jornadas hábiles en dos meses consecutivos», en virtud de la cual se requiere además «que el total de faltas de asistencia en los doce meses anteriores alcance el cinco por ciento de las jornadas hábiles».

5 Vid. González Ortega, S. (1983). Absentismo y despido del trabajador. Pamplona: Aranzadi, pág. 210, y Arias Domínguez, A. (2010). La reforma laboral de 2010. Cizur Menor (Navarra): Aranzadi, pág. 222.

6 Vid. Gualda Alcalá, F. J. (2011). «El absentismo como causa de despido objetivo», en A. Baylos Grau (coord.) (2011). Garantías de empleo y derechos laborales en la Ley 35/2010 de Reforma Laboral. Albacete: Bomarzo, pág. 217. 
Con esta exigencia se matiza un poco el excesivo rigor de esta previsión, al exigirse que se acredite más claramente la inasistencia persistente del trabajador al trabajo con el consiguiente perjuicio que ello ocasiona al empresario. En definitiva, en estos supuestos se requiere el cumplimiento de una doble exigencia: por una parte, que el trabajador acredite faltas de asistencia al trabajo, aun justificadas pero intermitentes, que alcancen el $20 \%$ de las jornadas hábiles en dos meses consecutivos; y, por otra, que el total de faltas de asistencia de este al trabajo en los doce meses anteriores alcance el $5 \%$ de las jornadas hábiles.

\section{B) La supresión definitiva de la exigencia de acreditar un determinado indice de absentismo colectivo}

Tras la aprobación del Real Decreto-Ley 10/2010, de 16 de junio, de medidas urgentes para la reforma del mercado de trabajo (en adelante, Real Decreto-Ley 10/2010), y la posterior tramitación y aprobación de la Ley 35/2010, de 17 de septiembre, de medidas urgentes para la reforma del mercado de trabajo (en adelante, Ley 35/2010), el porcentaje finalmente exigido para que se cumpliera el índice de absentismo total de la plantilla del centro de trabajo por el artículo 52 d) ET pasó del 5\% al 2,5\%. En consecuencia, aunque finalmente la Ley 35/2010 no eliminó totalmente la exigencia de un determinado nivel de absentismo global en la empresa para que pudiera operar esta causa de extinción del contrato como se demandaba desde diferentes ámbitos-, sí que la limitó sustancialmente al reducirse en un nada despreciable 50\%. Así, tras la reforma laboral del 2010 el nivel de absentismo global de la empresa que se consideraba que suponía una anomalía en la gestión del personal que trascendía de una concreta relación laboral por presentar una dimensión colectiva se fijó en el 2,5\%. Este pasó a ser, por lo tanto, el porcentaje que atribuía al empresario la facultad de extinguir el contrato de trabajo por considerarse que los niveles globales de absentismo que soportaba eran altos, presumiéndose en este punto que ello le acarreaba una disfunción o perjuicio importante para el normal funcionamiento de la empresa. Este porcentaje adolecía, sin embargo, del mismo inconveniente que planteaba el porcentaje del $5 \%$ previsto con anterioridad, y es que se fijaba con carácter general sin tener en cuenta las características específicas de cada sector de actividad y sin tener en cuenta, por lo tanto, que un mismo porcentaje de absentismo en un sector de actividad puede constituir una anomalía en la gestión ordinaria del personal, mientras que en otro, no.

Con independencia de la valoración que debía merecer esta modificación legislativa, resultaba indiscutible que siendo el índice de absentismo total de la plantilla del centro de trabajo un requisito para la aplicación de esta causa de ex- 
tinción del contrato, la reducción del porcentaje de absentismo colectivo exigido tenía que facilitar de un modo significativo el recurso por parte del empresario a ella, no en vano con anterioridad a la reforma laboral del 2010 se consideraba casi de forma unánime que la exigencia de que debía alcanzarse un índice de absentismo total de la plantilla del centro de trabajo tan elevado había sido la responsable de la escasa operatividad práctica de esta causa de extinción del contrato ${ }^{7}$. Por el contrario, la reducción tan significativa de este porcentaje de absentismo total de la plantilla, que tras la reforma de 2010 se redujo a la mitad, debía traducirse en una mayor facilidad para que el empresario pudiera poner fin a la relación laboral sobre la base de las ausencias del trabajador.

Las valoraciones que mereció esta medida en el seno de la doctrina fueron dispares. Así, mientras que algunos autores alabaron esta reforma por considerar que «la mejora introducida por el legislador en esta cuestión es indudable» en la medida en que «ha intentado por medio de esta vía dotar de mayor operatividad a una causa extintiva en desuso, precisamente por las dificultades halladas por las empresas para probar el cumplimiento de los niveles de absentismo - individual y colectivo- exigidos por la norma» ${ }^{8}$, otros autores se manifestaron mucho más cautos y críticos respecto a esta al considerar que «la lógica reformista de esta institución se inscribe, como toda la reforma laboral, en aumentar la capacidad de disposición del empresario sobre la vigencia de la relación laboral, al permitir una mayor aplicabilidad de esta vía de extinción, pues los índices de absentismo colectivo se rebajan a la mitad, de tal forma que del $5 \%$ que venía estableciendo el ET, se pasa al 2,5\% que establece la Ley 35/2010»?.

En todo caso, como ya se ha indicado con anterioridad, una limitación tan sustancial de la exigencia de que el empresario sufriera un determinado nivel de absentismo global para poder proceder a la extinción del contrato de trabajo como la que se llevó a cabo mediante la Ley 35/2010 tenía que incidir de un modo irremisible en la finalidad económico-social de esta causa de extinción del contrato de trabajo, puesto que permitía al empresario proceder a la extinción

7 Vid. González Díaz, F. A. (2010). «Despidos objetivos», en F. Cavas Martínez y J. Luján Alcaraz (coords.) (2010). Guía práctica de la reforma laboral de 2010. Murcia: Ediciones Laborum, pág. 197.

8 Vid. Alzaga Ruiz, I. (2011). «El absentismo del trabajador...», cit., pág. 403, y Blasco Pellicer, A. (2010). «La reforma de la extinción del contrato de trabajo en el RDL 10/2010», en C. L. Alfonso Mellado, A. Blasco Pellicer, L. M. Camps Ruiz y J. M. Goerlich Peset (2010). La reforma laboral en el Real Decreto-Ley 10/2010. Valencia: Tirant lo Blanch, pág. 94.

9 Vid. Gualda Alcalá, F. J. (2011). «El absentismo como causa...», cit., pág. 213. En esta dirección, Molina Navarrete, C. (2010). «Un nuevo acto del «gran teatro» de la reforma laboral 2010: una reforma «para reformar» o de la «galería de los disparates»». Revista de Trabajo y Seguridad Social. CEF, núm. 331, consideró que la reforma «ha tenido a bien nada menos que flexibilizar hasta el extremo la posibilidad de acudir al despido objetivo en situaciones de absentismo [...] para ello ha reformado, de forma inquietante a mi juicio, el artículo 52 letra d) del ET, reduciendo un $50 \%$ el porcentaje de absentismo necesario para poder llevar a cabo un despido objetivo». 
de la relación laboral en cuanto se constatara la excesiva onerosidad que para él suponían las faltas de asistencia al trabajo de un determinado trabajador, siendo suficiente con que paralelamente se constataran unos perjuicios para el normal funcionamiento y la productividad de la empresa derivados del nivel global de absentismo muy inferiores a los exigidos hasta el momento, en concreto, un $50 \%$ inferiores a los exigidos con anterioridad a la reforma laboral de 2010 .

Como ya se ha indicado, el Real Decreto-Ley 3/2012 primero y la Ley 3/2012 después han incidido sustancialmente en esta cuestión al prever que el contrato de trabajo podrá extinguirse «por faltas de asistencia al trabajo, aun justificadas pero intermitentes, que alcancen el $20 \%$ de las jornadas hábiles en dos meses consecutivos siempre que en el total de faltas de asistencia en los doce meses anteriores alcance el cinco por ciento de las jornadas hábiles, o el $25 \%$ en cuatro meses discontinuos dentro de un período de doce meses». Como fácilmente puede observarse, la nueva redacción del artículo 52 d) ET elimina definitivamente el inciso final del párrafo primero de dicho precepto según el cual la extinción del contrato podía llevarse a cabo «siempre que el índice de absentismo total de la plantilla del centro de trabajo supere el 2,5\% en los mismos períodos de tiempo». En consecuencia, la nueva redacción del artículo 52 d) ET introducida por la reforma laboral del 2012 no es que limite como hiciera la Ley 35/2010, sino que suprime totalmente el tradicional requisito del absentismo total de la plantilla para poder llevar a cabo la extinción del contrato prevista en esta norma, siendo suficiente a partir de su entrada en vigor que concurran las faltas de asistencia al trabajo del trabajador en cuestión ${ }^{10}$.

La supresión del requisito del absentismo total de la plantilla tiene importantes consecuencias; no en vano, mientras que cuando la normativa anterior posibilitaba la extinción de un contrato de trabajo lo hacía teniendo en cuenta no únicamente las faltas de asistencia de un determinado trabajador, sino también atendiendo al nivel de absentismo global existente en el centro de trabajo, de modo que solo se amparaba la decisión extintiva del empresario cuando los niveles globales de absentismo que soportaba eran altos y, por lo tanto, comportaban una disfunción o perjuicio importante para el normal funcionamiento de la empresa, tras la reforma laboral de 2012 la extinción del contrato de trabajo del trabajador ausente será posible con independencia de los niveles globales de absentismo que soporte el empresario. La supresión del requisito del absentismo total de la plantilla va a suponer, por lo tanto, un indiscutible debilitamiento de esta causa de extinción del contrato; no en vano, al suprimirse el umbral colecti-

10 Vid. Luján Alcaraz, J., Martínez Moya, J. y Ríos Mestre, J. M. (2012). «Medidas para mejorar la eficiencia del mercado de trabajo y reducir la dualidad laboral», en F. Cavas Martínez (coord.) (2012). La reforma laboral de 2012. Murcia: Ediciones Laborum, pág. 203. 
vo de absentismo se hace desaparecer el único elemento objetivo con que poder presumir, que no acreditar, un perjuicio al empresario por inasistencia ${ }^{11}$. Se introduce así de un modo buscado por el legislador una fuerte presión a renunciar a situaciones de ausencia al trabajo plenamente justificadas por el miedo a estar por encima de los umbrales fijados en la normativa ${ }^{12}$.

No faltan, sin embargo, voces que consideran razonable la supresión de la exigencia concurrente del nivel de absentismo de la plantilla del centro de trabajo en aras a superar la situación anterior, en que la regulación de esta causa de extinción del contrato resultaba tan compleja, rígida y exigente que acababa convirtiendo esta causa de extinción en poco o nada operativa ${ }^{13}$. Asimismo, también se había considerado que la existencia de este requisito hacía de esta causa de extinción del contrato un modelo de solución poco justa puesto que podía funcionar de forma diferente en función de la dimensión de la empresa y de la repercusión concreta que el índice de absentismo individual podía tener sobre el de conjunto. En definitiva, se considera que la eliminación de la referencia colectiva al absentismo permite solucionar todos estos problemas, permitiendo el despido cuando el absentismo individualmente acreditado supere los límites de razonabilidad establecidos en el artículo 52 d) ET ${ }^{14}$.

Más allá de las valoraciones que deba merecer la supresión del requisito del absentismo total de la plantilla, se han planteado las dificultades prácticas que pueden darse a la entrada en vigor de esta nueva redacción del artículo $52 \mathrm{~d}$ ) ET. En esta dirección, se ha indicado que «puede resultar problemático a la hora de tomar una decisión de despido por absentismo si las ausencias que provocan el cese (verificadas en un momento anterior a la entrada en vigor del RDLML) son susceptibles de ser tenidas en cuenta sin considerar el absentismo total de la plantilla del centro». A tal efecto, se mantiene que «desde luego, cabe el despido por ausencias anteriores, al amparo de la nueva redacción, cuando concurriese el requisito de absentismo colectivo que venía recogiendo la norma»; por el contrario, se considera que «es dudoso si cabe el despido cuando concurre la causa solo al amparo de la nueva redacción (que no de la vieja)». A favor de que proceda esta extinción se han alegado varios argumentos: «la norma no descarta esta aplica-

11 Vid. Ruiz Castillo, M. M. (2012). «La última modificación legal del despido por absentismo desde la nueva panorámica del despido en la reforma de 2012». Revista de Derecho Social, núm. 57, pág. 217. La autora considera, sin embargo, que los efectos de esta medida no son muy relevantes, sino de incidencia media, no en vano la reducción anterior del umbral del absentismo colectivo por la Ley 35/2010 hasta el 2,5 ya había diluido mucho esta exigencia.

12 De esta opinión, Molina Navarrete, C. (2012). «De las «reformas laborales»., », cit., pág. 118.

13 Vid. Blasco Pellicer, A. (2012). «La extinción del contrato de trabajo en el RDL 3/2012: aspectos sustantivos, procesales y de Seguridad Social», en A. Blasco Pellicer, L. M. Camps Ruiz, J. M. Goerlich Peset, R. Roqueta Buj y T. Sala Franco (2012). La reforma laboral en el Real Decreto-Ley 3/2012. Valencia: Tirant lo Blanch, pág. 209.

14 Vid. Goerlich Peset, J. M. (2012) «La extinción del contrato de trabajo...», cit., pág. 297. 
ción y está en vigor»; «no se trata de una sanción (despido disciplinario), sino de una medida de rentabilidad empresarial». En contra, se ha alegado que «se acaban valorando unos hechos con arreglo a norma posterior a su acaecimiento, en contra de la seguridad jurídica y con cierta semejanza a una restricción de derechos retroactiva» ${ }^{15}$.

\subsection{El procedimiento de la extinción del contrato por absentismo del trabajador}

Para poder extinguir el contrato de trabajo por causas objetivas, el artículo 53.1 ET exige la observancia de los siguientes requisitos formales: 1) comunicación escrita al trabajador; 2) la puesta a disposición del trabajador de la indemnización; 3) la concesión de un plazo de preaviso y de licencia para buscar nuevo empleo. En cualquier caso, estos requisitos son de carácter mínimo, de modo que mediante convenio colectivo podrán establecerse garantías adicionales para los trabajadores.

La primera exigencia que debe observarse para proceder a la extinción del contrato por causas objetivas consiste en la «comunicación escrita al trabajador expresando la causa» (art. 53.1.a) ET). En consecuencia, debe comunicarse por escrito al trabajador, mediante la conocida como carta de despido, la causa que motiva la extinción de su contrato. La finalidad perseguida con esta exigencia es garantizar los derechos de defensa del trabajador; no en vano, al conocer las razones que motivan la extinción de su contrato, podrá articular su defensa frente a esta decisión empresarial. La comunicación escrita debe recoger la causa que motiva la extinción del contrato, debiéndose hacer constar a tal efecto los hechos particulares que integran la concreta causa invocada. Sobre el nivel de concreción de esta comunicación y en relación con la extinción del contrato por ausencias del trabajador, la STSJ de Cataluña de 29 de enero de 1993 ya disponía que, aunque no nos encontramos ante un despido disciplinario, «dicha comunicación ha de contener una referencia a la causa extintiva lo suficientemente expresiva para que el trabajador pueda organizar su defensa y no se halle en situación de indefensión, concretamente en la del art. 52 d) viene exigiendo la doctrina que se hagan constar los períodos de inasistencia y la causa de ella». En consecuencia, la citada resolución considera que «este requisito no se cumple en la comunicación empresarial que se limita a decir que él total de faltas de asistencia han sido 28

15 Vid. el planteamiento de la cuestión y sus posibles soluciones en Sempere Navarro, A. V. y Martín Jiménez, R. (2012). Claves para la reforma laboral de 2010 (Estudio del RDley 3/2012, de 10 de febrero). Cizur Menor (Navarra): Thomson-Reuters Aranzadi, págs. 237 y 238. 
días hábiles en un período de cuatro meses consecutivos dentro de los doce meses indicados'». Según el Tribunal, «dicha referencia es insuficiente para que el trabajador pueda conocer cuáles son las bajas por enfermedad a las que se refiere la carta de extinción del contrato privándole en consecuencia del derecho a combatir tales afirmaciones con las necesarias garantías $»^{16}$.

El segundo requisito que debe satisfacerse para proceder a la extinción del contrato por causas objetivas consiste en "poner a disposición del trabajador, simultáneamente a la entrega de la comunicación escrita, la indemnización de veinte días por año de servicio, prorrateándose por meses los períodos de tiempo inferiores a un año y con un máximo de doce mensualidades» (art. 53.1.b) ET). En consecuencia, de forma simultánea a la entrega de la comunicación escrita, el empresario ha de poner a disposición del trabajador la indemnización que se acaba de indicar. La jurisprudencia ha fijado como requisitos de esta puesta a disposición de la indemnización la concreción del importe de la indemnización y la efectiva puesta a disposición de dicha cantidad. El pago de la indemnización debe hacerse en el mismo momento de la comunicación o facilitarse de forma simultánea, con indicación en la comunicación por escrito de la forma en que se hará efectivo el pago, sin que en ningún caso pueda estar condicionado, es decir, sin que pueda exigirse ningún trámite complementario al trabajador para proceder a la entrega de la cantidad adeudada. En todo caso, la percepción de la indemnización no supone conformidad con la decisión empresarial ni, en consecuencia, enerva la acción correspondiente. Si bien, como se indicará más adelante, el incumplimiento de este requisito origina la improcedencia de la extinción del contrato de trabajo efectuada, no conlleva este efecto el error excusable en el cálculo de la indemnización puesta a disposición del trabajador, sin perjuicio de que en estos supuestos deba procederse a un nuevo cálculo de esta y al abono al trabajador por parte del empresario de la indemnización en la cuantía correcta.

El tercer requisito que debe satisfacer el empresario para proceder a la extinción del contrato por causas objetivas consiste en la «concesión de un plazo de preaviso de quince días, computado desde la entrega de la comunicación personal al trabajador hasta la extinción del contrato de trabajo» (art. 53.1.c) ET). La principal finalidad de este período de preaviso consiste en posibilitar al trabajador la búsqueda de un nuevo empleo, para lo cual el artículo 53.2 ET prevé que «durante el período de preaviso el trabajador, o su representante legal si se trata de un disminuido que lo tuviera, tendrá derecho, sin pérdida de su retribución, a una licencia de seis horas semanales con el fin de buscar nuevo empleo». Esta

16 En esta dirección, Gualda Alcalá, F. J. (2011). «El absentismo como causa...», cit., pág. 222, indica que en la comunicación extintiva habrán de concretarse la totalidad de las faltas de asistencia que se imputan al trabajador y que fundamentan la extinción de su contrato de trabajo. 
licencia se configura como una interrupción de la prestación laboral, correspondiendo al trabajador, previa comunicación al empresario, determinar el momento exacto de su disfrute.

El incumplimiento del preaviso no afecta a la validez de la extinción del contrato, puesto que la extinción realizada sin cumplir este requisito produce plenos efectos, sin perjuicio de la obligación del empresario de abonar al trabajador los salarios correspondientes al número de días que se ha dejado de preavisar. Asimismo, el incumplimiento de la obligación de conceder al trabajador la licencia para buscar empleo únicamente genera la obligación de abonar estas horas de trabajo al trabajador.

\subsection{La calificación y los efectos de la extinción del contrato por absentismo del trabajador}

El artículo 53.3 ET prevé la posibilidad de que el trabajador pueda recurrir contra la decisión extintiva basada en las ausencias al trabajo del trabajador como si se tratara de un despido disciplinario, para lo cual dispone de un plazo de veinte días hábiles a contar a partir del día siguiente al de la extinción del contrato. Pese a ello, el trabajador puede anticipar el ejercicio de la acción a partir del momento en que reciba la comunicación empresarial de preaviso. La percepción efectiva por parte del trabajador de la indemnización que debe poner a su disposición el empleador, así como el uso de la licencia que se le concede durante el período de preaviso, no suponen la conformidad con la decisión empresarial y, en consecuencia, no enervan el derecho del trabajador a reclamar jurisdiccionalmente. La impugnación de la decisión empresarial debe tramitarse a través de la modalidad procesal específica prevista en los artículos 120 a 124 de la Ley 36/2011, de 10 de octubre, reguladora de la jurisdicción social (en adelante, Ley 36/2011).

Una vez impugnada por vía jurisdiccional la extinción del contrato de trabajo por causas objetivas, el órgano judicial encargado de su conocimiento puede calificar dicha extinción contractual como procedente, improcedente o nula en los términos y con los efectos previstos en los apartados 4 y 5 del artículo 53 ET.

El órgano judicial calificará la extinción del contrato como procedente cuando se cumplan los requisitos formales exigidos para esta modalidad de extinción contractual y se acrediten las causas alegadas por el empresario para proceder a ella. En consecuencia, dos son los requisitos exigidos para que el órgano judicial emita la declaración de procedencia: que se hayan cumplido las exigencias procedimentales previstas para estas extinciones y que queden acreditadas las 
circunstancias alegadas por la empresa en la comunicación escrita para justificar la extinción del contrato. En estos supuestos, la sentencia procede a declarar extinguido el contrato de trabajo, convalidando la decisión extintiva empresarial y reconociéndose al trabajador el derecho a percibir la indemnización prevista en el artículo 53.1.b) ET, es decir, la de veinte días de salario por año de servicio, prorrateándose por meses los períodos de tiempo inferiores a un año y con un máximo de doce mensualidades, que en el caso de haberla ya recibido el trabajador la consolidará. Asimismo, se entenderá que el trabajador se encuentra en situación de desempleo por causa a él no imputable.

Si la indemnización puesta a disposición del trabajador ha sido calculada erróneamente por el empresario de un modo excusable o si el plazo de preaviso se hubiese incumplido, la sentencia que declare la procedencia del despido objetivo condenará también al empresario a satisfacer al trabajador las diferencias que pudieran existir entre la indemnización que ya hubiese percibido y la que legalmente le corresponda, así como también a abonarle los salarios correspondientes al período de preaviso omitido.

La extinción del contrato de trabajo por causas objetivas se considerará improcedente cuando no se acredite la concurrencia de la causa en que se fundamentó la decisión extintiva o cuando no se hubieren cumplido los requisitos exigidos para proceder a esta vía de extinción del contrato de trabajo (art. 53.4 ET). En consecuencia, son dos los supuestos en que el órgano judicial procederá a declarar la improcedencia de la extinción del contrato de trabajo: en primer lugar, por no acreditarse las causas alegadas por el empresario como justificativas de su decisión extintiva y, en segundo lugar, por incumplirse los requisitos formales de esta modalidad de extinción contractual (comunicación escrita y puesta a disposición de la indemnización pertinente). En este punto cabe recordar que la no concesión de preaviso o el error excusable en el cálculo de la indemnización no determinarán la improcedencia del despido, sin perjuicio de la obligación del empresario de abonar los salarios correspondientes a dicho período o de pagar la indemnización en la cuantía correcta.

Para el supuesto en que la extinción del contrato por causas objetivas sea declarada improcedente, la nueva redacción del artículo 56 ET establece que en el supuesto en que la opción correspondiera al empresario y se efectuase a favor de la indemnización, no se devengarán salarios de tramitación y la indemnización a abonar será de treinta y tres días de salario por año de servicio, prorrateándose por meses los períodos de tiempo inferiores al año, hasta un máximo de veinticuatro mensualidades. En el caso de que se opte por la readmisión, el trabajador tendrá derecho a los salarios de tramitación. Si el despedido fuera un represen- 
tante legal de los trabajadores o un delegado sindical, la opción corresponderá siempre a este. Cuando la opción, expresa o presunta, sea a favor de la readmisión, esta será obligada. En estos supuestos, tanto si se opta por la indemnización como por la readmisión, se tendrá derecho a los salarios de tramitación. Siendo esta materia objeto de estudio pormenorizado al analizarse los efectos del despido disciplinario por ausencias del trabajador, nos remitimos a este.

Finalmente, la decisión empresarial de extinguir el contrato por causas objetivas podrá ser calificada como nula en los siguientes casos‡1) cuando sea discriminatoria o contraria a derechos fundamentales y libertades públicas del trabajador; 2) cuando se produce la extinción del contrato de trabajo por causas objetivas no justificadas de los siguientes colectivos de trabajadores: a) trabajadores durante el período de suspensión del contrato por maternidad, riesgo durante el embarazo, riesgo durante la lactancia natural, enfermedades causadas por embarazo, parto o lactancia natural, adopción o acogimiento o paternidad a que se refiere el artículo 45.1.d) ET, o el notificado en una fecha tal que el plazo de preaviso concedido finalice dentro de dicho período; b) trabajadoras embarazadas desde la fecha de inicio del embarazo o trabajadores que hayan solicitado alguno de los permisos del artículo 37.4. 4 bis y 5 ET o estén disfrutando de ellos o hayan solicitado la excedencia prevista en el artículo 46.3 ET, así como también las trabajadoras víctimas de violencia de género por el ejercicio de los derechos de reducción o reordenación de su tiempo de trabajo, de movilidad geográfica, de cambio de centro de trabajo o de suspensión de la relación laboral; y c) trabajadores que se han reintegrado al trabajo al finalizar los períodos de suspensión del contrato por maternidad, adopción o acogimiento o paternidad, siempre que no hubieran transcurrido más de nueve meses desde la fecha de nacimiento, adopción o acogimiento de hijo. En todos estos supuestos, para que se declare la nulidad de la decisión extintiva del empresario, esta debe ser injustificada, de modo que no se declarará la nulidad cuando se establezca la procedencia de la decisión extintiva por motivos no relacionados con el embarazo o con el ejercicio del derecho a los permisos y la excedencia señalados; 3) cuando tratándose de extinciones del contrato por causas económicas, técnicas, organizativas o de producción, estas se hayan realizado en fraude de ley eludiendo las normas establecidas para los despidos colectivos (art. 122.2.b) de la Ley 36/2011, de 10 de octubre, reguladora de la jurisdicción social).

En los supuestos en que la extinción del contrato de trabajo por causas objetivas sea declarada nula, se condenará al empresario a la readmisión inmediata del trabajador con abono de los salarios dejados de percibir. En estos supuestos, al ser readmitido el trabajador en la empresa deberá reintegrar la indemnización percibida. 


\section{Las ausencias del trabajador como causa de despido disciplinario tras la Ley 3/2012}

\subsection{Las faltas repetidas de puntualidad y asistencia al trabajo como causa del despido disciplinario}

El despido disciplinario se articula como un mecanismo de reacción del empresario frente a los incumplimientos del trabajador en el marco de la relación de trabajo, el cual encuentra su justificación en la facultad sancionadora que le reconoce el ordenamiento jurídico-laboral. No obstante, este instrumento sancionador no puede hacerse efectivo ante cualquier tipo de incumplimiento contractual del trabajador, sino que este, en coherencia con los efectos extintivos que produce y tal y como indica el artículo 54.1 ET, solo puede utilizarse ante un incumplimiento que ha de ser grave y culpable e influir en la relación laboral, lo cual ha de entenderse en el sentido de que, en primer lugar, la conducta del trabajador debe afectar a las obligaciones que nacen del contrato de trabajo, de ahí que la enumeración prevista en el artículo 54 ET sea una relación de incumplimientos contractuales; en segundo lugar, que tales incumplimientos sean relevantes en el desarrollo de la prestación de servicios, ya que de lo contrario la respuesta del empresario sería desproporcionada a la conducta realizada; y, en tercer lugar, que el incumplimiento se produzca por el concurso de la voluntad del trabajador, al requerir de la existencia de dolo, negligencia o culpa ${ }^{17}$.

Sobre la base de estas premisas, el artículo 54.2 ET realiza una enumeración de conductas que responden a las exigencias que la ley entiende que deben concurrir para que el empresario pueda sancionar a un trabajador con el despido, entre las cuales se encuentra citada en primer lugar las «faltas repetidas e injustificadas de asistencia e impuntualidad» (art.54.2 a) ET).

La causa que regula las ausencias del trabajador como despido disciplinario no ha sufrido ninguna variación tras la aprobación de la Ley 3/2012, lo cual significa que se mantiene la misma formulación conceptual de esta causa extintiva.

El artículo 54.2 a) ET establece como motivos que permiten al empresario sancionar al trabajador con el despido disciplinario las ausencias al trabajo y las faltas de puntualidad. Por lo tanto, nos encontramos ante dos situaciones/conductas diferentes que permitirán la adopción de una decisión extintiva de carácter unilateral por parte del empresario. La incorporación de dos conductas diferentes en una misma causa justificativa de un despido disciplinario se encuentra en la concurrencia de un elemento común en ambos supuestos que es el

17 Aguilera Izquiero, R. (1997). Las causas del despido disciplinario y su valoración por la jurisprudencia. Cizur Menor (Navarra): Aranzadi, págs. 23 y 24. 
no cumplimiento de la prestación de servicios durante los tiempos convenidos por las partes contratantes como jornada de trabajo ${ }^{18}$. A su vez, la diferencia entre un supuesto y otro se encuentra en la duración que tienen dichas ausencias. De esta manera, la falta de puntualidad o la impuntualidad se identifica con ausencias que no abarcan la totalidad de la jornada laboral diaria, produciéndose una ausencia al inicio, durante o al final de la jornada diaria, pero contando a lo largo de esta con la presencia del trabajador, mientras que la falta de asistencia al trabajo supone la prolongación de la ausencia del trabajador a lo largo de una o varias jornadas laborales. Por lo tanto, mientras que las faltas de puntualidad son ausencias parciales durante la jornada de trabajo, las faltas de asistencia implican una ausencia total durante la jornada laboral ${ }^{19}$.

Esta construcción doctrinal tiene su origen en la delimitación conceptual que a lo largo de los años han venido realizando los tribunales, existiendo en estos momentos una jurisprudencia consolidada al respecto. En este sentido, se ha indicado de forma reiterada que la falta de puntualidad se produce si el trabajador llega tarde al trabajo, si se marcha antes de lo debido o también cuando se ausenta durante la jornada laboral ${ }^{20}$, mientras que la falta de asistencia se identifica con no «acudir a la faena diaria» ${ }^{21}$.

Junto a la constatación del hecho de la ausencia o la falta de puntualidad del trabajador, el artículo 54.1 ET requiere, para que dicha conducta sea susceptible de sancionarse como despido disciplinario, que el incumplimiento pueda ser calificado de «grave y culpable».

En relación con la determinación de qué ausencias o faltas de puntualidad en el trabajo caben calificarse como un incumplimiento grave, existe acuerdo doctrinal en considerar que la exigencia de la «repetición» del incumplimiento del trabajador prevista para estos casos es un elemento de valoración de la «gravedad» de la conducta ${ }^{22}$. Ahora bien, el número concreto de repeticiones exigidas

18 Vid., entre otros, Poquet Català, R. (2001). La actual configuración del poder disciplinario empresarial. Valencia: Tirant lo Blanch, pág. 123, y Rubio Medina, M. D. (2000). El despido disciplinario. Barcelona: Bosch, pág. 15.

19 Aguilera Izquiero, R. (1997). Las causas del despido..., cit., pág. 242.

20 Vid. SSTS de 2 de julio de 1986 (RJ 3927/1986) y de 19 de octubre de 1990 (RJ 1990, 7932). Más recientemente, STSJ Castilla-La Mancha de 30 de marzo de 2006 (Ar. 1060/2006).

21 Vid. STS de 5 de julio de 1973 (RJ 3274/1973).

22 En este sentido se manifiestan, entre otros, Aguilera Izquiero, R. (1997). Las causas del despido..., cit. pág. 245; Alonso Olea, M. (2004). Derecho del Trabajo. Madrid: Thomson-Civitas, pág. 482; Gómez Abelleira, F. J (2009). «Las causas disciplinarias del despido», en A. V. Sempere Navarro (dir.) y R. Martín Rivérez (coord.) (2009). Despido Disciplinario. Cizur Menor (Navarra): Thomson-Aranzadi, pág. 186; González-Posada Martínez, E. (2009). «La noción de incumplimiento contractual grave y culpable en la jurisprudencia», en J. L. Gil Gil y J. M. del Valle (coords.) (2009). El despido disciplinario. Madrid: Ediciones Cinca, pág. 113; y Montoya Melgar, A. (2004). Derecho del Trabajo. Madrid: Tecnos, pág. 457. 
no viene previsto por la ley, por lo que serán las normas convencionales sobre la base del artículo 58 ET las que deberán aportar ese nivel de concreción.

Al hilo del papel tan significativo que se reserva a las normas sectoriales en la configuración de la causa extintiva prevista en el artículo 54.2 a) ET, se plantea la cuestión del alcance que en la práctica tienen dichas normas en relación con la función interpretativa de la normativa que se encomienda a los órganos judiciales, en el sentido de valorar si la noción de gravedad de las faltas de asistencia y puntualidad al trabajo recae en exclusiva en la concreción del número de repeticiones de un mismo incumplimiento en el desarrollo de la prestación laboral o, si por el contrario, se admiten criterios y elementos adicionales para la determinación de la concurrencia de la gravedad en una conducta susceptible de sancionarse con un despido disciplinario. En otros términos, se plantea la duda de si el grado de gravedad de un incumplimiento consistente en faltas repetidas de asistencia o puntualidad se reduce a una cuestión cuantitativa, $y$, por lo tanto, los tribunales se limitan a constatar el número de ausencias exigidas por las normas sectoriales para determinar el carácter procedente de un despido disciplinario o si existe margen de actuación para los tribunales pese al cumplimiento numérico de ausencias previstas en dichas normas.

La respuesta dada por los tribunales a esta cuestión no es unánime $y$, tal y como indica Aguilera Izquierdo ${ }^{23}$, se pueden distinguir dos posiciones diferentes. Una postura aboga por que la gravedad del incumplimiento solo dependa de las repeticiones de las faltas de asistencia o puntualidad, independientemente de las circunstancias concurrentes en cada $\mathrm{caso}^{24}$, afirmándose que en estos casos no cabe la teoría gradualista ${ }^{25}$. Otra posición, por el contrario, defiende la necesidad de realizar un análisis minucioso y detallado de cada caso en concreto. Se rechaza la consideración de que las faltas de asistencia y puntualidad operen como causas automáticas y objetivas, entendiendo que la gravedad ha de individualizarse en función de los actos realizados por el trabajador y los efectos que se producen en la empresa y, por lo tanto, defiende la aplicación de la «teoría gradualista» ${ }^{26}$.

23 Aguilera Izquiero, R. (1997). Las causas del despido..., cit. págs. 246 y ss.

24 Este criterio está presente, entre otras, en la STSJ Madrid de 31 de marzo de 2008 (AS 2008/1651), la STSJ La Rioja de 28 de febrero de 2006 (AS 2006/735) y la STSJ Murcia de 17 de octubre de 2005 (AS 2006/1110).

25 STSJ Madrid de 15 de enero de 2008 (AS 2008/916).

26 STS de 20 de diciembre de 1985 (RJ 1985, 6160). En este mismo sentido se expresan, por ejemplo, la STSJ Cataluña de 25 de mayo de 1999 (AS 1999/1435), la STSJ Extremadura de 17 de noviembre de 1997 (AS 1997/4228) y la STSJ Canarias (Santa Cruz de Tenerife) de 17 de febrero de 1998 (AS 1998/482), y más recientemente, la STSJ Cataluña de 18 de enero de 2001 (JUR 2001/99544), las SSTSJ Canarias (Santa Cruz de Tenerife) de 16 de octubre de 2000 (AS 2000/4338) y de 23 de abril de 2002 (JUR 2002/167485) y la STSJ Madrid de 15 de julio de 2003 (JUR 2003/249719). 
A nivel doctrinal, la postura que se mantiene de forma mayoritaria es la que defiende la aplicación por parte de los tribunales de la «teoría gradualista» ${ }^{27}$, posición que también compartimos ya que, a nuestro parecer, el cumplimiento del principio de proporcionalidad que informa al poder sancionador del empresario (art. 58 ET) requiere que la valoración de la gravedad se realice ponderando las ausencias en el trabajo en relación con las circunstancias que se producen en el caso concreto $y$, en consecuencia, valorando los atenuantes o agravantes que lo acompañan; solo de esa forma se puede conseguir una correcta adecuación del incumplimiento del trabajador a la sanción aplicable a este.

Junto a la gravedad del incumplimiento cometido por el trabajador, un segundo elemento en torno al cual gira la configuración de las causas del despido disciplinario es el carácter culpable de la conducta cometida.

La claridad con la que se expresa el precepto a la hora de exigir la concurrencia de culpabilidad en la conducta realizada por el trabajador no tiene su traslación a la hora de concretar el alcance que en la práctica ha de tener esta exigencia ya que no existe una opinión clara y unánime en relación con los elementos que deben concurrir en un incumplimiento para que este pueda calificarse como una conducta culpable. De esta forma y en relación con las ausencias y faltas de puntualidad en el trabajo, es razonable, como ha señalado la jurisprudencia, vincular la culpabilidad del incumplimiento a su falta de justificación ${ }^{28}$ por cuanto el propio artículo 54.2 a) ET se refiere expresamente a que esas faltas sean injustificadas, además de que el carácter injustificado es la calificación que lleva a que tales incumplimientos no puedan reconducirse hacia otra causa extintiva prevista por la misma normativa laboral como es la extinción por causas objetivas del artículo 52 d) ET.

Ahora bien, por otro lado y tal y como señala la doctrina desde un punto de vista dogmático, la referencia a la culpabilidad conduce a la existencia de una acción culpable en sus dos vertientes: la acción reprochable no ha de tener justificación, pero en ella debe concurrir también dolo o culpa ${ }^{29}$. Es decir, se plantea la necesidad de que en esa conducta que supone un incumplimiento de los deberes básicos del trabajador y que no encuentra ninguna razón justificable intervenga, en mayor o menor medida, la voluntad del trabajador.

\footnotetext{
27 Posición mantenida, entre otros, por Aguilera Izquiero, R. (1997). Las causas del despido..., cit. págs. 247 y ss.; Bidón y Vigil de Quiñones, J. I. (2001). El despido disciplinario y sus causas. Granada: Comares, pág. 300; Delgado Ucelay, I. (1992). «Las faltas repetidas e injustificadas de asistencia al trabajo», en AA. VV. (1992). Estudios sobre el despido disciplinario. Madrid: ACARL, pág. 128; Gómez Abelleira, J. F. (2009). La causalidad del despido disciplinario. Madrid: Civitas-Thomson Reuters, pág. 98; y Ortiz Lallana, M. C. (2000). «Causas, forma y efectos del despido disciplinario». Revista Española de Derecho del Trabajo, núm. 100, pág. 1.127.

28 Opinión referida por Aguilera Izquiero, R. (1997). Las causas del despido..., cit. pág. 254.

29 González-Posada Martínez, E. (2009). «La noción de incumplimiento...», cit. pág. 118.
} 
En relación con la exigencia de la concurrencia de dolo o culpa en las faltas de puntualidad y asistencia en el trabajo, la doctrina no acaba de posicionarse claramente a favor de dicha opción, ya que algunos autores consideran que no es necesaria la concurrencia de dolo o culpa ${ }^{30}$, mientras que otros consideran que la «responsabilidad» exigible al trabajador en su conducta ha de estar presente en esta causa extintiva y se incardina en la determinación del carácter justificado o no del incumplimiento cometido ${ }^{31}$.

A nuestro parecer y siguiendo las pautas que hasta el momento marca la doctrina judicial, la falta de justificación de la ausencia o la falta de puntualidad del trabajador y la concurrencia de dolo o culpa son dos elementos inescindibles para poder determinar aquellas conductas que serán susceptibles de ser sancionadas con un despido disciplinario. Por lo tanto, deben actuar como vasos comunicantes en la configuración de la causa extintiva de despido, retroalimentándose mutuamente para delimitar las conductas susceptibles de ser sancionadas. De esta forma, entendemos que una ausencia o falta de puntualidad en el trabajo que carezca de justificación legal se configura a priori como una conducta susceptible de ser sancionada con el despido disciplinario al considerarse que existe una presunción iuris tantum de que tal conducta es culpable. Ahora bien, tal configuración requiere que dicha conducta se valore teniendo en cuenta el contexto personal, profesional, social, etcétera, del trabajador en que se produce dicho incumplimiento injustificado, realizando una ponderación de los motivos que le llevan a no asistir al trabajo o a incurrir en impuntualidades para poder concluir si efectivamente cabe calificar dicha conducta verdaderamente como causa de despido disciplinario.

A este respecto, existe una importante doctrina judicial que se ha ido consolidando a lo largo de los años sobre los supuestos de inasistencia al trabajo que se enmarcan o no dentro del artículo 54.2 a) ET en función del contexto en el que se desarrollan y que son principalmente los siguientes:

30 Pedrajas Moreno, A. y Sala Franco, T. (2009). Ausencias en el trabajo y absentismo. Valencia: Tirant lo Blanch, pág. 17, se expresan claramente al indicar lo siguiente: «Las faltas de asistencia o de puntualidad al trabajo, cuando sean repetidas e injustificadas, son calificadas por el art. 54.2 a) ET de causa de despido disciplinario. De esta forma, el precepto indicado traduce al supuesto contemplado las exigencias genéricas que para el despido disciplinario imponen en el art. 54.1 ET: la nota de gravedad vendrá referida a la reiteración y la de culpabilidad a la injustificación». En esta misma línea, Cámara Botía, A. (1997). «El carácter culpable del cumplimiento del trabajador en el despido disciplinario», en J. Gárate Castro (coord.) (1997). Cuestiones actuales del despido disciplinario. Santiago de Compostela: Universidad de Santiago de Compostela, señala que «[...] es evidente que en ciertas causas típicas de despido resulta absurdo plantearse si en el incumplimiento concurre o no dolo o culpa. Piénsese así en las faltas de asistencia al trabajo [... ], se trata de un supuesto en el que la prestación misma falta, por lo que obviamente también faltará su modo de ser que es la diligencia (no diligencia = negligencia = culpa = culpable, ex art. 54.1 ET)».

31 Vid., Gómez Abelleira, F. J. (2009), «Las causas disciplinarias del despido», en A. V. Sempere Navarro (dir.) y R. Martín Rivérez (coord.) (2009). Despido Disciplinario. Cizur Menor (Navarra): Thomson-Aranzadi, págs. 170 y 192, y Delgado Ucelay, I. (1992). «Las faltas repetidas...», cit. pág. 131. 


\section{A) Incumplimientos vinculados al ejercicio de permisos y descansos periódicos del trabajador}

En este apartado destacan los incumplimientos ligados al disfrute de vacaciones. En este sentido, la falta de autorización por parte de la empresa del disfrute de las vacaciones constituye una conducta que se sanciona con el despido ${ }^{32}$, y de igual forma cabe calificar el supuesto en el que el trabajador se extralimita en el disfrute del período de vacaciones reconocido ${ }^{33}$, siempre y cuando no se pueda constatar la existencia de circunstancias ajenas a la voluntad del trabajador que le hayan impedido su reincorporación ${ }^{34}$. Sin embargo, a nuestro parecer quedan excluidos de esta calificación aquellos casos en los que, sin existir acuerdo expreso, tácitamente se desprende el acuerdo entre las partes ${ }^{35}$, aquellos casos en los que el trabajador no ha podido conocer la negativa expresada por la empresa ${ }^{36}$, así como los supuestos en que, aun existiendo el acuerdo previo para el disfrute de las vacaciones, en un momento determinado y antes de iniciarse estas la empresa revoca la autorización ${ }^{37}$.

Junto al disfrute de vacaciones cabe destacar también el disfrute de permisos no periódicos. La casuística relacionada con la causa prevista en el artículo 54.2 a) ET gira en torno, en primer lugar, a la exigencia de «comunicación previa» al empresario que se establece en el artículo 37.3 ET. A este respecto, cabe indicar que los tribunales, aunque no de forma unánime, han venido flexibilizando dicha exigencia formal de manera que, aunque dicha comunicación no se produzca y concurran los motivos previstos por la norma legal o convencional, se considera que la ausencia es justificada y, en consecuencia, se declara el despido improcedente. Y, en segundo lugar, en torno a la extralimitación del período correspondiente a los permisos reconocidos ya sea por vía legal, convencional o contractual.

32 Vid., entre otras, la STSJ Castilla y León (Burgos) de 11 de febrero de 2010 (AS 2010/941), la STSJ Castilla-La Mancha de 27 de enero de 2009 (JUR 2009/323671) y la STSJ Extremadura de 13 de junio de 2006 (AS 2006/2073).

33 Vid., entre otras, la STSJ Baleares de 17 de diciembre de 2007 (AS 2008/758), la STSJ País Vasco de 11 de septiembre de 2007 (JUR 2008/35804), la STSJ Extremadura de 5 de octubre de 2006 (AS 2007/207) y la STSJ Aragón de 29 de marzo de 2006 (JUR 2006/241146).

34 Así, por ejemplo, en la STSJ Cataluña de 19 de abril de 2010 (AS 2010/1622) se declara como despido improcedente el realizado por una empresa como consecuencia del retraso del trabajador en su incorporación al trabajo una vez superado el período de vacaciones que tenía concedido ya que dicho trabajador se ve imposibilitado de acudir a su puesto de trabajo al verse afectado por problemas de traslado.

35 En este sentido, por ejemplo, en la STSJ Madrid de 7 de julio de 2000 (AS 2000/4716) se declara el despido improcedente porque el trabajador, pese a que no ha recibido la autorización expresa de la empresa para disfrutar del período de vacaciones, se ha conducido siguiendo los usos y costumbres que en esta materia se venían aplicando en la empresa. Vid. también, entre otras, la STS de 19 de julio de 1988 (RJ 6191), la STSJ Andalucía (Málaga) de 21 de junio de 1996 (AS 1996/1763) y la STSJ País Vasco de 30 de septiembre de 1993 (AS 1993/4142).

36 Así se expresa la STSJ Canarias de 25 de febrero de 2008 (JUR 2008/183360).

37 Vid., por todas, la STSJ Castilla-La Mancha de 15 de marzo de 2007 (JUR 2007/214909). 
A tal efecto, la solución practicada hasta el momento es la declaración del despido como procedente, considerándose, por lo tanto, en estos casos que las circunstancias acaecidas se ajustan a la causa extintiva contenida en el artículo 54.2 a) ET ${ }^{38}$.

\section{B) Ausencias motivadas por razones de salud. Las bajas de IT}

En este apartado el aspecto más relevante es la justificación formal de la situación de IT. En este punto existe una jurisprudencia consolidada del Tribunal Supremo que parte de la consideración de la necesaria acreditación por parte del trabajador de la situación de incapacidad temporal a efectos de que las ausencias del trabajador no constituyan causa de despido disciplinario sobre la base del artículo 54.2 a) ET, de manera que cuando falta dicha acreditación se considera que tales ausencias no están justificadas y, en consecuencia, pueden ser sancionadas con el despido disciplinario ${ }^{39}$. Esta postura ha llevado a que en algunos casos los tribunales hayan calificado un despido disciplinario como procedente por no existir la presentación de los partes médicos de baja a pesar de que la empresa ha sido informada de la enfermedad del trabajador ${ }^{40}$.

Sobre la base de la anterior premisa interpretativa que ofrece el Tribunal Supremo, se abre un amplio abanico de situaciones referidas a la acreditación de la IT que llevan a que los tribunales, en especial los tribunales superiores de justicia, en ocasiones incluyan en el supuesto del artículo 54.2 a) ET las ausencias del trabajador por enfermedad o accidente. Así sucede en los casos en que no se produce la reincorporación del trabajador una vez recibida el alta médica ${ }^{41} \mathrm{o}$ cuando se impugna el alta médica por parte del trabajador ${ }^{42}$. En sentido contrario se manifiestan los tribunales cuando se trata de retrasos en la presentación de los

38 Vid., a modo de ejemplo, la STSJ Comunidad Valenciana de 10 de marzo de 2005 (AS 2005/1160), que declara el despido realizado por una empresa como procedente por cuanto el trabajador se excede en el número de días de permiso concedido por nacimiento de hijo, y la STSJ Cataluña de 18 de enero de 2006 (JUR 2006/88630), que declara también procedente el despido disciplinario realizado por el disfrute del permiso de matrimonio concedido al trabajador más allá de los días asignados para dicho permiso.

39 Vid. las SSTS de 4 de junio de 1986 (RJ 1986/3461), de 9 de diciembre de 1983 (RJ 1983/6183) y de 17 de diciembre de 1982 (RJ 1982/7834).

40 STSJ Cataluña de 14 de octubre de 1992 (AS 1992/5104).

41 Vid. la STS de 7 de octubre de 2004 (RJ 2004/7889) y la STSJ Cataluña de 4 de febrero de 2009 (JUR 2009/192143).

42 Vid. la STSJ Andalucía (Granada) de 25 de mayo de 2011 (AS 2011/2649) y la STSJ Cataluña de 23 de septiembre de 2008 (AS 2008/3178). 
partes de baja ${ }^{43}$ o cuando pese a existir el alta de IT a efectos económicos queda demostrada la falta de recuperación médica del trabajador ${ }^{44}$.

C) Ausencias motivadas por privación de libertad del trabajador

En este apartado debe distinguirse el supuesto de causa suspensiva previsto en el artículo $45.1 \mathrm{~g}$ ) ET de los supuestos que quedan encuadrados como despido disciplinario. Tal y como establece la normativa laboral, mientras no exista una sentencia condenatoria firme de prisión el trabajador verá suspendida la relación de trabajo. Esta previsión tiene un claro vínculo con la aplicación del principio constitucional de presunción de inocencia (art. 24.2 CE), que debe presidir todo proceso penal y que pretende tutelar los derechos de quien, incurso en un proceso como sospechoso e imputado de algún delito tipificado por el Código Penal, se ve apartado temporalmente de su puesto de trabajo ${ }^{45}$. Se trata, por lo tanto, de un supuesto que se dirige a evitar perjuicios adicionales a aquellos que se derivan de su propio procesamiento ${ }^{46}$. De no considerarse así, una actuación ilícita de las autoridades podría producir efectos irreparables tales como la privación de los medios de subsistencia de quien más tarde será absuelto ${ }^{47}$.

Sin embargo, si la privación de libertad se produce a partir de una sentencia firme, las ausencias que se produzcan a partir de ese momento podrán computar a efectos del cumplimento de los requisitos previstos por el artículo 54.2 a) ET. A este respecto, el Tribunal Supremo mantiene inalterada su doctrina, recogida en sentencias como la dictada el 28 de febrero de $1990^{48}$ y seguida por los tribunales superiores de justicia ${ }^{49}$, por la cual se considera que en tales casos las ausencias derivadas del cumplimiento de la sentencia condenatoria firme de privación de libertad dejan de tener la cobertura de la suspensión del contrato, pasando a configurarse como un incumplimiento laboral sancionable por el empresario. La solución que nos ofrece la jurisprudencia parte de la constatación de que el trabajador, al haber cometido un delito que le lleva legítimamente a ser privado de su libertad, se

43 Vid., entre otras, la STSJ País Vasco de 30 de octubre de 2007 (JUR 2008/40750), la STSJ Madrid de 4 de abril de 2006 (AS 2006/1723) y las SSTSJ Cataluña de 12 de diciembre de 2006 (AS 2007/1298) y de 21 de julio de 2006 (AS 2007/187).

44 Vid. la STSJ Galicia de 21 de julio de 2008 (AS 2008/1947), confirmada en unificación de doctrina por la STS de 21 de julio de 2009 (RJ 2009/6119). Un comentario sobre esta sentencia en Moreno Cáliz, S.: «Incapacidad temporal y despido disciplinario», Aranzadi Social, núm. 79/2008.

45 Vid., por todos, Rivas Vallejo, M. P. (2007). La suspensión del contrato de trabajo. Naturaleza jurídica y supuestos legales. Albacete: Bomarzo, pág. 188.

46 Puebla Pinilla, A. de la (2011). «Causas y efectos de la suspensión del contrato», en L. E. de la Villa Gil (dir.) (2011). Comentarios al Estatuto de los Trabajadores. Madrid: Iustel.

47 Rodríguez Devesa, J. M. (1974). «La privación de libertad del trabajador». Revista de Política Social, núm. 95, pág. 139.

48 RJ 1990/1247.

49 Vid., por todas, la STSJ Andalucía (Granada) de 22 de diciembre de 2010 (AS 2011/799). 
ve imposibilitado de dar cumplimiento a su prestación de servicios profesionales, violando así la diligencia que le es exigible en su esfera privada tendente a posibilitar el posterior cumplimiento de sus deberes laborales, lo cual le hace concurrir en la causa de despido disciplinario por ausencias repetidas al trabajo ${ }^{50}$.

D) Otros supuestos de ausencia al trabajo

A los supuestos anteriores cabe añadir otros casos que de forma menos habitual plantean su inclusión como causa de despido disciplinario, entre los que destacamos dos. El primero se refiere al disfrute de la suspensión por motivos de maternidad y a la interpretación que debe realizarse de la falta de cumplimiento del régimen legal previsto para esta situación. $\mathrm{Al}$ respecto y en coherencia con el criterio general seguido en la interpretación de esta causa extintiva, se atiende a las circunstancias concurrentes para valorar la existencia o no de culpabilidad en la conducta del trabajador ${ }^{51}$.

El segundo corresponde al ejercicio del derecho de excedencia y, concretamente, en relación con el cumplimiento de los requisitos formales y de duración. A este respecto y en relación con la excedencia voluntaria, la jurisprudencia ha entendido que la efectividad del derecho solo es posible si existe autorización previa por parte del empresario, ya sea con carácter tácito o expreso ${ }^{52}$. Este criterio no es de aplicación en el caso de que nos encontremos ante supuestos de excedencia para cuidado de hijos, al entenderse que en tales casos es suficiente con la notificación previa al empresario ${ }^{53}$. En cuanto a la extralimitación en la duración de la situación de excedencia, sea esta forzosa o voluntaria, cabe distinguir entre la extralimitación que se produce como consecuencia del tiempo que debe esperar el trabajador que desea reincorporarse hasta su efectiva incorporación, que no se puede considerar como ausencias injustificadas ${ }^{54}$, y el tiempo que transcurre desde que se produce la autorización de la empresa hasta la reincorporación efectiva del trabajador, ya que en este último caso sí que se interpreta la existencia de una ausencia injustificada al trabajo constitutiva de despido disciplinario ${ }^{55}$.

50 Barreiro González, G. (1981). Diligencia y negligencia en el cumplimiento. Madrid: Centro de Estudios Constitucionales, pág. 399.

51 Vid., por ejemplo, la STSJ Andalucía (Málaga) de 27 de octubre de 2005 (AS 2006/175).

52 Vid. la STS de 5 de julio de 1990 (RJ 1009/6058). Este criterio se recoge, entre otras sentencias, en la STSJ Castilla y León (Valladolid) de 3 de diciembre de 2010 (AS 2011/711) y la STSJ Castilla-La Mancha de 23 de mayo de 2008 (AS 2008/1961).

53 En este sentido se expresa la STSJ Navarra de 4 de mayo de 2006 (AS 2006/1628) y la STSJ País Vasco de 29 de abril de 2003 (AS 2003/2633).

54 STS de 1 de octubre de 1986 (RJ 1986/5359).

55 STS de 4 de noviembre de 1983 (RJ 1983/5648). 


\section{$2.2 \mathrm{El}$ procedimiento de despido disciplinario}

Tampoco se ha visto afectado por la nueva reforma laboral de 2012 el procedimiento a seguir para hacer efectivo el despido disciplinario. De esta forma, si concurren los elementos configuradores previstos para que las faltas de asistencia o puntualidad puedan sancionarse con despido, el empresario está obligado a respetar, al margen de lo previsto en negociación colectiva, las siguientes formalidades ${ }^{56}$ :

1. Notificación de la extinción por el empresario al trabajador. La notificación debe realizarse por escrito (carta de despido) indicando los hechos que lo motivan y la fecha en que tendrá efecto (art. 55.1 ET). Dicha notificación debe realizarse personalmente al trabajador, debiendo de poner el empresario todos los medios razonables para ello. En caso de tratarse de un trabajador afiliado a algún sindicato, los delegados sindicales deberán ser oídos por la empresa previamente a la notificación, siempre que al empresario le conste dicha afiliación, y, en todo caso, el empresario está obligado a informar al comité de empresa de todos los despidos efectuados.

2. Apertura de expediente contradictorio. En el caso de que el trabajador despedido fuera un representante de los trabajadores y dando cumplimiento a lo previsto en los artículos 68 a) ET y 10.3 LOLS, el empresario está obligado a abrir un expediente contradictorio en el que deben ser oídos, además del interesado, el comité de empresa o el resto de delegados de personal. Esta garantía abarca el mandato completo del representante y el año siguiente a su expiración. De igual forma, será de aplicación a los representantes electos, así como a los candidatos proclamados mientras dure el proceso electoral.

3. Plazo de ejercicio de la facultad disciplinaria. El artículo 60 ET fija unos plazos máximos para el ejercicio del poder disciplinario del empresario, los cuales están en función de la gravedad de la infracción cometida. El despido disciplinario, en cuanto falta muy grave, está sometido a un plazo de prescripción de 60 días contados desde la fecha en que el empresario tiene conocimiento del incumplimiento, los cuales deberán englobarse dentro del plazo de 6 meses desde la comisión de la falta que se quiere sancionar.

Una vez cumplidos los requisitos formales anteriormente indicados, el despido disciplinario se hará efectivo, lo cual comportará la extinción del contrato en la fecha fijada en la carta de despido. Este tipo de extinción del contrato, por cuanto sanción, no viene acompañada de ningún tipo de indemnización para el

56 Un completo estudio sobre el procedimiento del despido disciplinario se encuentra en Matorras DíazCaneja, A. (2009). El despido disciplinario: forma, lugar, tiempo, calificación y efectos. Cizur Menor (Navarra): Aranzadi-Thomson Reuters. 
trabajador, si bien dicha extinción permitirá al trabajador, siempre que cumpla los requisitos marcados por el sistema de la Seguridad Social, percibir la correspondiente prestación por desempleo.

\subsection{Calificación y efectos del despido disciplinario}

Una vez comunicado el despido por parte del empresario, el trabajador destinatario de dicha medida sancionadora puede impugnar por vía judicial la decisión empresarial. El procedimiento a seguir es el regulado en los artículos 103 a 113 de la Ley 36/2011, la cual, pese a su corto período de vigencia, ya se ha visto modificada por la Ley $3 / 2012^{57}$ debido a la necesaria adecuación de la nueva ley procesal a los importantes cambios que se han introducido, ahora sí, en este ámbito de la regulación del despido disciplinario y, concretamente, en relación con los efectos de este.

Efectivamente, tal y como ya se anunciaba en el RD-Ley 3/2012 y después de un largo proceso de reformas legales iniciadas en 199458, la Ley 3/2012 da el paso definitivo, aunque desafortunadamente nada asegura que sea el último, en el «abaratamiento» del despido improcedente, ya que en este supuesto los costes empresariales se ven reducidos doblemente: por una parte, en relación con los salarios de tramitación y, por otra, en la cuantía mínima a pagar en concepto de indemnización al trabajador.

Pero antes de abordar el estudio de los cambios operados por la Ley 3/2012 en relación con los efectos del despido disciplinario y por lo que se refiere a la calificación del despido, cabe indicar que en este ámbito no se han producido cambios y, tal y como se venía indicando hasta ahora por la norma, la decisión judicial puede tener como resultado la calificación del despido como:

a) Procedente, decisión que supone confirmar la extinción del contrato de trabajo realizada por el empresario y, por lo tanto, declarar que se han cumplido los requisitos formales exigidos para realizar el despido y que las razones alegadas por el empresario han quedado acreditadas en juicio (art. 55.4 ET). En tal caso, la extinción del contrato no se acompaña ni del pago de salarios de tramitación ni de ningún tipo de indemnización.

b) Improcedente, declaración que se producirá cuando el empresario no haya cumplido los requisitos formales exigidos por la ley para llevar a cabo el despido o cuando las razones alegadas para llevarlo a cabo no hayan quedado acreditadas

57 Concretamente, el artículo 23 de la Ley 3/2012 modifica los artículos 110.1 y 111.1 b) de la Ley 36/2011. 58 Para un estudio de las diferentes reformas laborales que se han ido produciendo en relación con la reducción de los costes del despido improcedente, Vid. Fernández López, M. F. (2012). «La reforma del régimen del despido por la vía de la reducción de sus costes». Revista de Derecho Social, núm. 57, pág. 199 y ss. 
en juicio (art. 56.1 ET). En este caso y pese a los cambios realizados por la Ley $3 / 2012$, se mantiene la opción a favor del empresario, salvo que el trabajador afectado sea un representante legal de los trabajadores, de readmitir al trabajador o bien rescindir el contrato previo pago de una indemnización.

c) Nulo. La nulidad del despido se producirá cuando tenga como móvil alguna de las causas de discriminación prohibidas en la Constitución y en la ley o cuando se produzca la violación de derechos fundamentales y libertades públicas. Asimismo, el despido también será calificado como nulo en los siguientes supuestos: a) trabajadores durante el período de suspensión del contrato por maternidad, riesgo durante el embarazo, riesgo durante la lactancia natural, enfermedades causadas por embarazo, parto o lactancia natural, adopción o acogimiento o paternidad a que se refiere el artículo 45.1.d) ET, o el notificado en una fecha tal que el plazo de preaviso concedido finalice dentro de dicho período; b) trabajadoras embarazadas desde la fecha de inicio del embarazo o trabajadores que hayan solicitado alguno de los permisos del artículo 37.4.4 bis y 5 ET o estén disfrutando de ellos o hayan solicitado la excedencia prevista en el artículo 46.3 ET, así como también las trabajadoras víctimas de violencia de género por el ejercicio de los derechos de reducción o reordenación de su tiempo de trabajo, de movilidad geográfica, de cambio de centro de trabajo o de suspensión de la relación laboral; y c) trabajadores que se han reintegrado al trabajo al finalizar los períodos de suspensión del contrato por maternidad, adopción o acogimiento o paternidad, siempre que no hubieran transcurrido más de nueve meses desde la fecha de nacimiento, adopción o acogimiento de hijo. En todos estos supuestos, para que se declare la nulidad de la decisión extintiva del empresario, esta debe ser injustificada, de modo que no se declarará la nulidad cuando se establezca la procedencia de la decisión extintiva por motivos no relacionados con el embarazo o con el ejercicio del derecho a los permisos y la excedencia señalados.

La declaración de nulidad del despido supone que el empresario está obligado a la readmisión del trabajador con el pago de los salarios dejados de percibir desde la fecha del despido hasta la fecha de notificación de la resolución judicial (art. 55.6 ET).

Pese al mantenimiento de la calificación del despido disciplinario y como ya hemos adelantado al principio de este apartado, la Ley 3/2012 introduce diversos cambios muy importantes en relación con los efectos que se derivan de la declaración del despido como improcedente.

Un primer cambio es la reducción en la cuantía de la indemnización a la que tiene derecho el trabajador cuando se opta por la rescisión del contrato de trabajo, ya que se pasa del pago de 45 días de salario por año trabajado con un máximo 
de 42 mensualidades al de 33 días de salario por año trabajado con un máximo de 24 mensualidades. Esta reducción se justifica por el legislador con argumentos un tanto discutibles ${ }^{59}$ recogidos ya por el RD-Ley 3/2012 y que se reproducen en la exposición de motivos de la Ley $3 / 2012^{60}$, según los cuales «mejorar la eficiencia del mercado de trabajo y reducir la dualidad laboral» exige «acercar los costes del despido a la media europea». Ello ha supuesto la generalización de la reducción del coste de la extinción del contrato, de manera que la indemnización reducida que estaba únicamente presente en el contrato de fomento de la contratación indefinida ha pasado a aplicarse a todo tipo de contrato cuya extinción se declare improcedente, sin olvidar que también afecta a los supuestos de extinción del contrato del artículo 50.2 ET, ya que dicho precepto sigue remitiéndose al artículo 56.1 ET.

El segundo gran cambio afecta al pago de los salarios de tramitación. Como es sabido, hasta la reforma de 2012, con independencia de si se optaba por la readmisión o la indemnización en los despidos improcedentes, se debían abonar al trabajador los salarios dejados de percibir desde la fecha de despido hasta la notificación de la sentencia que declarase la improcedencia o hasta que hubiera encontrado otro empleo si tal colocación fuera anterior a dicha sentencia y se probase por el empresario lo percibido para su descuento. Es decir, el trabajador tenía derecho al cobro de los «salarios de tramitación».

No obstante lo anterior, el artículo 56.2 ET excluía la obligación del empresario de abonar los salarios de tramitación en aquellos casos en que reconociera la improcedencia del despido y depositara en el Juzgado de lo Social a disposición del trabajador la indemnización correspondiente en el plazo de 48 horas desde el despido. En estos supuestos, comúnmente denominados de «despido exprés», el despido improcedente no devengaba salarios de tramitación.

Pues bien, la Ley 3/2012 cambia el régimen de los salarios de tramitación, de forma que solo se mantienen para los casos en los que se opte por la readmisión del trabajador, de manera que si la opción es la extinción del contrato, el trabajador solo recibirá la indemnización reducida de 33 días de salario, sin derecho a salarios de tramitación. Esta regla tiene su excepción en el caso de que el trabajador afectado tenga la condición de representante legal de los trabajadores, en cuyo caso siempre, con independencia de la opción, percibirá los salarios de tramitación.

59 En este sentido se manifiesta Goerlich Peset, J. M. (2012). «La extinción del contrato de trabajo...», cit. pág. 311 .

$60 \mathrm{Vid}$. apartado $\mathrm{V}$. 
Con este nuevo régimen jurídico de los salarios de tramitación, y tal y como ya anuncia la propia Ley 3/2012 en su exposición de motivos ${ }^{61}$, desaparece la figura del «despido exprés», pero lejos de suponer un reforzamiento de dichos salarios, la nueva regulación prima las extinciones indemnizadas y correlativamente castiga las readmisiones ${ }^{62}$.

Por otro lado, la rebaja de los salarios de tramitación también afecta a otros ámbitos, ya que con su eliminación se desactivan los tiempos de negociación conciliadora o transaccional, y se eliminan las cotizaciones correspondientes a dichos salarios, así como también los costes procesales de reclamación más allá de los 60 días si se opta por la extinción ${ }^{63}$.

En un momento de crisis económica en el que parece imprescindible contar con mecanismos que permitan garantizar el cada vez más escaso empleo, nos encontramos con una respuesta legislativa que, a nuestro parecer, se contradice con este objetivo ya que, lejos de reforzarse los medios que aseguren el trabajo en supuestos de despidos injustos, se dota a la norma de elementos que precisamente favorecen lo contrario al ofrecer la generalización en la eliminación de los salarios de tramitación y reducir los costes del despido ${ }^{64}$. De nuevo olvida el legislador que un despido improcedente es aquel que se declara previa revisión judicial como injusto por no mediar ninguna causa objetiva y razonable que justifique la extinción del contrato de trabajo y que, a pesar de ello, permite al empresario mantener su decisión arrebatando al trabajador su medio de subsistencia, que es el trabajo.

\section{Bibliografía}

Aguilera Izquierdo, R. (1997). Las causas del despido disciplinario y su valoración por la jurisprudencia. Cizur Menor (Navarra): Aranzadi.

Altés Tárrega, J. A.; Blasco Pellicer, A. y Nores Torres, L. E. (2010). El despido objetivo. Valencia: Tirant lo Blanch.

Alzaga Ruiz, I. (2011). «El absentismo del trabajador como causa de despido objetivo». Revista Española de Derecho del Trabajo, núm. 150.

Arias Domínguez, A. (2010). La reforma laboral de 2010. Cizur Menor (Navarra): Aranzadi.

61 Vid. apartado III.

62 Blasco Pellicer, A.: «La extinción del contrato de trabajo...», cit. pág. 156.

63Molina Navarrete, C. (2012). «De las «reformas laborales»...», cit. pág. 90.

64 En palabras del profesor Molina Navarrete, en los últimos dos años hemos pasado de la imagen de un «despido libre, pero costoso» a un «despido libre, y mucho más barato», y ya se han dado los primeros pasos con el nuevo contrato para emprendedores hacia el «despido libre y gratuito». Ibíd. pág. 90 y 91. 
Barreiro González, G. (1981). Diligencia y negligencia en el cumplimiento. Madrid: Centro de Estudios Constitucionales.

Bidón y Vigil de Quiñones, J. I. (2001). El despido disciplinario y sus causas. Granada: Comares.

Blasco Pellicer, A. (2010). «La reforma de la extinción del contrato de trabajo en el RDL 10/2010», en C. L. Alfonso Mellado, A. Blasco Pellicer, L. M. Camps Ruiz y J. M. Goerlich Peset (2010). La reforma laboral en el Real Decreto-Ley 10/2010. Valencia: Tirant lo Blanch.

Blasco Pellicer, A. (2012). «La extinción del contrato de trabajo en el RDL 3/2012: aspectos sustantivos, procesales y de Seguridad Social», en A. Blasco Pellicer, L. M.; Camps Ruiz, J. M.; Goerlich Peset, R.; Roqueta Buj y T. Sala Franco (2012). La reforma laboral en el Real Decreto-Ley 3/2012. Valencia: Tirant lo Blanch.

Cámara Botía, A. (1997). «El carácter culpable del cumplimiento del trabajador en el despido disciplinario», en J. Gárate Castro (coord.) (1997). Cuestiones actuales del despido disciplinario. Santiago de Compostela: Universidad de Santiago de Compostela.

Delgado Ucelay, I. (1992). «Las faltas repetidas e injustificadas de asistencia al trabajo», en AA. VV. (1992). Estudios sobre el despido disciplinario. Madrid: ACARL.

Fernández López, M. F. (2012). «La reforma del régimen del despido por la vía de la reducción de sus costes». Revista de Derecho Social, núm. 57.

Goerlich Peset, J. M. (2012). «La extinción del contrato de trabajo en el Real Decreto-Ley 3/2012: la culminación de una larga evolución», en I. GarcíaPerrote Escartín y J. R. Mercader Uguina (2012). Reforma laboral 2012. Valladolid: Lex Nova,

Gómez Abelleira, J. F. (2009), La causalidad del despido disciplinario. Madrid: Civitas-Thomson Reuters.

Gómez Abelleira, F. J. (2009). «Las causas disciplinarias del despido», en A. V. Sempere Navarro (dir.) y R. Martín Rivérez (coord.) (2009). Despido Disciplinario. Cizur Menor (Navarra): Thomson-Aranzadi.

González Díaz, F. A. (2010). «Despidos objetivos», en F. Cavas Martínez y J. Luján Alcaraz (coords.) (2010). Guía práctica de la reforma laboral de 2010. Murcia: Ediciones Laborum.

González Ortega, S. (1983). Absentismo y despido del trabajador. Pamplona: Aranzadi. 
González-Posada Martínez, E. (2009). «La noción de incumplimiento contractual grave y culpable en la jurisprudencia», en J. L. Gil Gil y J. M. DeL VAlle (coords.) (2009). El despido disciplinario. Madrid: Ediciones Cinca.

Gualda Alcalá, F. J. (2011). «El absentismo como causa de despido objetivo», en A. Baylos Grau (coord.) (2011). Garantías de empleo y derechos laborales en la Ley 35/2010 de Reforma Laboral. Albacete: Bomarzo.

Luján Alcaraz, J.; Martínez Moya, J. y Ríos Mestre, J. M. (2012). «Medidas para mejorar la eficiencia del mercado de trabajo y reducir la dualidad laboral», en F. Cavas Martínez (coord.) (2012). La reforma laboral de 2012. Murcia: Ediciones Laborum.

Matorras Díaz-Caneja, A. (2009). El despido disciplinario: forma, lugar, tiempo, calificación y efectos. Cizur Menor (Navarra): Aranzadi-Thomson Reuters. Molina Navarrete, C. (2012). «De las «reformas laborales» a un nuevo, e irreconocible, «estatuto del trabajo subordinado»». Revista de Trabajo y Seguridad Social, núm. 348.

Molina Navarrete, C. (2010)+ «Un nuevo acto del «gran teatro» de la reforma laboral 2010: una reforma "para reformar» o de la "galería de los disparates»». Revista de Trabajo y Seguridad Social. CEF, núm. 331.

Ortiz Lallana, M. C. (2000). «Causas, forma y efectos del despido disciplinario». Revista Española de Derecho del Trabajo, núm. 100.

Pedrajas Moreno, A. y Sala Franco, T. (2009). Ausencias en el trabajo y absentismo. Valencia: Tirant lo Blanch.

Poquet Català, R. (2001). La actual configuración del poder disciplinario empresarial. Valencia: Tirant lo Blanch.

Puebla Pinilla, A. de la (2011). «Causas y efectos de la suspensión del contrato», en L. E. De la Villa Gil (dir.) (2011). Comentarios al Estatuto de los Trabajadores. Madrid: Iustel.

Rivas Vallejo, M. P. (2007). La suspensión del contrato de trabajo. Naturaleza jurídica y supuestos legales. Albacete: Bomarzo.

Rodríguez Devesa, J. M. (1974). «La privación de libertad del trabajador». Revista de Política Social, núm. 95.

Rubio Medina, M. D. (2000). El despido disciplinario. Barcelona: Bosch.

Ruiz Castillo, M. M. (2012). «La última modificación legal del despido por absentismo desde la nueva panorámica del despido en la reforma de 2012». Revista de Derecho Social, núm. 57.

Sempere Navarro, A. V·y Martín Jiménez, R. (2012). Claves para la reforma laboral de 2010 (Estudio del RDley 3/2012, de 10 de febrero). Cizur Menor (Navarra): Thomson-Reuters Aranzadi. 